\title{
The Effect of Over the Counter and Synthetic Vitamin B6 (Pyridoxine) and Vitamin B12 (Cyanocobalamin) on the Behavior of Liver and Non-Liver Cells
}

\author{
Adriatico Aileen ${ }^{1}$, Garcia Victor ${ }^{1}$, Vega Huerta Salvador ${ }^{1}$, Conway \\ Michelle $^{1}$ and Tawil Bill ${ }^{1,2 *}$ \\ ${ }^{1}$ Department of Biotechnology and Bioinformatics, California State University, \\ Channel Islands, USA \\ ${ }^{2}$ Department of Biomedical Engineering, University of California Los Angeles, USA \\ *Corresponding Author: Tawil Bill, Department of Biomedical Engineering, \\ University of California Los Angeles, USA.
}

Received: July 01, 2020

Published: August 26, 2020

(C) All rights are reserved by Tawil Bill., et al.

\begin{abstract}
The class B vitamins are involved in numerous essential metabolic pathways, it is critical to study the effects of these vitamins at length. In this study, the use of Human Foreskin Fibroblast (HFF) was used to optimize the Vitamin B concentration to be used later in Clone 9 (C9), liver epithelial cell line. The initial cell adhesion and cell proliferation percentages were measured at $5 \mathrm{ug} / \mathrm{mL}, 10$ $\mathrm{ug} / \mathrm{mL}$, and $20 \mathrm{ug} / \mathrm{mL}$ of synthetic and over the counter (OTC) formulations of Vitamins B6 and B12. In general, HFF-1 and Clone 9 cells displayed favorable rates of proliferation when treated with varying concentrations of Vitamin B6 and Vitamin B12 and the combination of these with concentrations of $5 \mathrm{ug} / \mathrm{mL}, 10 \mathrm{ug} / \mathrm{mL}$ and $20 \mathrm{ug} / \mathrm{mL}$. When administered separately, synthetic Vitamin B12 increased C9 cell proliferation more dramatically than synthetic Vitamin B6. The data suggests a synergistic effect increases cell proliferation the most. This is evident in combined synthetic vitamins B6 and B12 (10,000\% increase at $20 \mathrm{ug} / \mathrm{mL})$, but also present in the combined OTC vitamins B6 and B12 (6000\% increase at $20 \mathrm{ug} / \mathrm{mL})$. C9 cell morphology appears consistent in all the conditions except for the presence of dark pigmentation in the cells treated with combined B vitamins. The liver is an important organ in the body and performs a fundamental role in the regulation of metabolism, secretion, storage and detoxification. In conclusion, hepatic diseases are areas of concern, thus, it is necessary to identify substances for the treatment of liver diseases, protection of the liver and regeneration of hepatic cells.
\end{abstract}

Keywords: HFF-1; Human Foreskin Fibroblasts; Clone 9; Rat Hepatocytes; Synergy; Proliferation; Regeneration

\section{Abbreviations}

HFF-1: Human Foreskin Fibroblast; Vitamin B12; Vitamin B6; C9: Clone 9; Cells; Liver Cells; ECM: Extracellular Matrix

\section{Introduction}

B-complex supplements usually pack all eight B vitamins into one pill. They contain the following: B1 (thiamine), B2 (riboflavin), B3 (niacin), B5 (pantothenic acid), B6 (pyridoxine), B7 (biotin), B9 (folate) and B12 (cobalamin) (Healthline, 2019). These B-vitamins perform essential, closely interrelated roles in cellular functioning, acting as coenzymes in a vast array of catabolic and anabolic enzymatic reactions [1].

Among the several components of the B-complex vitamins, B12 (Cyanocobalamin/Cobalamin) and B6 (Pyridoxine) are the most widely studied [1]. Vitamin B12 acts as a coenzyme, as its presence alone is required for other enzyme-catalyzed reactions [2]. Vita- 
The Effect of Over the Counter and Synthetic Vitamin B6 (Pyridoxine) and Vitamin B12 (Cyanocobalamin) on the Behavior of Liver and Non-Liver Cells

min B12 uses MUT and MTR (methionine synthase) to catalyze its components [3]. The most well-known of all the B vitamins, B12 is vital for neurological function, DNA production and red blood cell development [2].

Vitamin B12 is water-soluble and produced by microorganisms. Humans cannot synthesize cobalamin systemically and are dependent on dietary sources alone. In the stomach, hydrochloric acid and enzymes unbind vitamin B12 into its free form and combines with a protein called intrinsic factor so that it can be absorbed further down in the small intestine (Harvard T.H. Chan, 2019). According to Chitambar., et al. [4], the recommended daily allowance of Vitamin B12 is $2.4 \mathrm{ug}$ for men and non-pregnant women and 2.6 ug for pregnant women. In a non-vegetarian diet, the main source of Vitamin B12 is intake of animal proteins and the average nonvegetarian Western diet will contain 5 to $7 \mathrm{ug}$ /day of this vitamin which is sufficient to maintain normal cobalamin homeostasis [5]. Vitamin B12 is necessary in key metabolic pathways involved in lipid, carbohydrate and protein metabolism; plays a significant role in hematopoiesis and essential for cellular respiration and energy by acting on the Krebs cycle; and maintenance of the central nervous system as it aids in myelination [5]. Its deficiency causes reversible megaloblastic anemia, demyelinating neurological disease, anemia, thrombocytopenia and pancytopenia [6].

Vitamin B6 is involved in amino acid metabolism, red blood cell production and the creation of neurotransmitter [7]. Pyridoxal 5' phosphate (PLP) and pyridoxamine 5' phosphate (PMP) are the active coenzyme forms of vitamin B6. Pyridoxal 5' phosphate (PLP) and pyridoxamine $5^{\prime}$ phosphate (PMP) are the active coenzyme forms of vitamin B6. According to the National Institutes of Health, " $11 \%$ of vitamin B6 supplement users and $24 \%$ of people in the United States who do not take supplements containing vitamin B6 have low plasma PLP concentrations (less than $20 \mathrm{nmol} / \mathrm{L}$ )" and The Food and Nutrition Board (FNB) at the Institute of Medicine of the National Academies used a plasma PLP level of $20 \mathrm{nmol} / \mathrm{L}$ as the major indicator of adequacy to calculate the Recommended Dietary Allowances (RDAs) for adults (Office of Dietary Supplements, 2019). Vitamin B6 deficiencies on their own are uncommon, "inadequate vitamin B6 status is usually associated with low concentrations of other B-complex vitamins, such as vitamin B12 and folic acid" [7]. However, vitamin B6 deficiencies have been shown to cause "microcytic anemia, electroencephalographic abnormali- ties, dermatitis with cheilosis (scaling on the lips and cracks at the corners of the mouth) and glossitis (swollen tongue), depression and confusion, and weakened immune function" [8]. Vitamin B6 deficiency can result from malabsorption syndromes, such as celiac disease, Crohn's disease, and ulcerative colitis. Vitamin B6 deficiencies are also found in individuals that have alcohol dependency. Since alcohol produces acetaldehyde, an alcohol dependent person will accumulate an extensive amount of acetaldehyde, which in turn, decreases net PLP formation by cells because of the competition between PLP in protein binding. "As a result, the PLP in cells might be more susceptible to hydrolysis by membrane-bound phosphatase", therefore, people with alcohol dependence might benefit from pyridoxine supplementation [8].

The liver is an important organ in the body and performs a fundamental role in the regulation of metabolism, secretion, storage and detoxification. Because of these functions, hepatic diseases are areas of concern, thus, it is necessary to identify substances for the treatment of liver diseases, protection of the liver or help regenerate hepatic cells. In this study, the use of Human foreskin fibroblast (HFF) was used to optimize the Vitamin B concentration to be used later in the liver cell line. HFF are used in biomedical research. A fibroblast is a type of biological cell that synthesizes the extracellular matrix and collagen, produces the structural framework (stroma) for animal tissues, and plays a critical role in wound healing [9]. Fibroblasts are the most common cells of connective tissue in animals. Fibroblast cells are spindle shaped, anchorage dependent, members of the connective tissue family, they secrete type I and III collagen into the ECM and play an important role in wound healing and immune response during tissue injury [10]. Fibroblast cells occur in connective tissue of animals and synthesize the extracellular matrix (ECM) which is made of growth factors and proteins that directly affect the differentiation, proliferation, and migration of cells (Da Rocha-Acevedo, 2013). Clone 9 cell line is from Rattus norvegicus, rat liver epithelial tissue $[11,12]$ and was used later in the study. It is from Sprague-Dawley strain and is used for studies of in vitro carcinogenesis and clonal assays for screening sera and other nutritional supplements [11].

In this study, both liver (Clone 9) and non-liver (HFF-1) cell lines displayed increased rates of proliferation when treated with different concentrations of over the counter and synthetic formulations of vitamin B6 and B12 for a period of 7 days. 
The Effect of Over the Counter and Synthetic Vitamin B6 (Pyridoxine) and Vitamin B12 (Cyanocobalamin) on the Behavior of Liver and Non-Liver Cells

\section{Materials and Methods}

HFF-1 and clone 9 cell culture

HFF-1 and Clone 9 cell solutions (ATCC, Manassas, VA, USA) were prepared separately in T75 flasks (Thermo ScientificTM, Waltham, MA, USA) and stored in an incubator (Thermo ScientificTM, Waltham, MA, USA) at $37^{\circ} \mathrm{C}$ and $5 \% \mathrm{CO}_{2}$. After confirmation of appropriate confluency via phase contrast microscope CKX41 (Olympus $^{\circledR}$, Shinjuku, Tokyo, Japan), existing media from the HFF-1 cells was removed. Cells were washed twice with $5 \mathrm{~mL}$ of phosphate buffer saline each time (PBS) (GE Healthcare, Chicago, IL, USA) and subsequently removed. Trypsinization of cells was performed by the addition of $5 \mathrm{~mL}$ of trypsin (GE Healthcare, Chicago, IL, USA), and the cells were allowed to rest for 10 minutes at room temperature to allow them to detach from surface of the flask. The flask was then examined under the phase contrast microscope to confirm detachment of cells from flask surface. For Clone 9 cells, similar procedure was performed with Clone 9 cell media. To stop and neutralize trypsin activity, $5 \mathrm{~mL}$ of media with serum was added to the flask. The total suspension of $10 \mathrm{~mL}$ was placed into a 15 mL conical centrifuge tube (Fisherbrand, Waltham, MA, USA) and subjected to centrifugation in a centrifuge (Eppendorf AG, Hamburg, Germany) at $200 \mathrm{rpm}$ for 5 minutes. The supernatant was then removed and the remaining pellet was resuspended in $1 \mathrm{~mL}$ of HFF-1 or Clone 9 media. $20 \mu \mathrm{L}$ of the cell solution was added to a cellometer cell counting chamber (Nexcelom Bioscience, Lawrence, MA, USA) and cell density was measured by the Cellometer Auto T4 (Nexcelom Bioscience, Lawrence, MA, USA) and average live cell concentration was calculated. Cell proliferation assays on 2D matrix were performed at different concentrations of over the counter Vitamin B12 (500mcg) and Vitamin B6 (100 mg) (Pharmavite ${ }^{\circledR}$ LLC., Mission Hills, CA 91346-9606, USA) and synthetic Vitamin B12 and Vitamin B6 (Sigma-Aldrich ${ }^{\circledR}$, St. Louis, MO, USA and Adooq ${ }^{\circledR}$ Bioscience LLC, Irvine, CA, USA) for both liver and non-liver cells.

\section{D HFF-1 cell proliferation assay}

Varying concentrations of over the counter vitamin b6 and vitamin b12 and combination of both vitamins

Vitamin B6 and Vitamin B12 stock solutions were created in HFF-1 media and filtered through Nalgene ${ }^{\mathrm{TM}} 25 \mathrm{~mm}$ Syringe Filters. Using a $50 \mathrm{~mL}$ conical tube, the OTC tablet was crushed and dissolved in a $20 \mathrm{uL}$ of the HFF-1 media and the resulting solution was filtered into a separate $50 \mathrm{~mL}$ conical tube. $5 \mathrm{ug} / \mathrm{mL}, 10 \mathrm{ug} / \mathrm{mL}$ and $20 \mathrm{ug} / \mathrm{mL}$ of Vitamin B12 and Vitamin B6 were created from standard stock by serial dilution method, and the $\mathrm{pH}$ of each solution was measured. Prior to cell seeding into cell culture, the three 24 well cell culture clusters were washed two times using $500 \mathrm{uL}$ of PBS in each well and vacuumed. HFF-1 cells with an initial cell density of 10,000 per well were seeded in 24 well culture cluster coated with $10 \mu \mathrm{g} / \mathrm{mL}$ collagen and grown in HFF-1 media. All three plates for day 1, day 3 and day 7 were prepared by the same method and placed inside the incubator set at $\left.37\right|^{\circ} \mathrm{C}$ with $5 \% \mathrm{CO}_{2}$.

\section{D clone 9 cell proliferation assay}

Clone 9 cells proliferation on varying substrates: Collagen and fibronectin

Three 24-well culture clusters (Corning Incorporated, Corning, NY, USA) were coated with either collagen $(5 \mu \mathrm{g} / \mathrm{mL})$, collagen (10 $\mu \mathrm{g} / \mathrm{mL})$, fibronectin $(5 \mu \mathrm{g} / \mathrm{mL})$, or fibronectin $(10 \mu \mathrm{g} / \mathrm{mL})$ as an extracellular matrix (Sigma-Aldrich ${ }^{\circledR}$, St. Louis, MO, USA). Prior to cell seeding into cell culture, the three 24 well cell culture clusters were washed two times using $500 \mathrm{uL}$ of PBS in each well and vacuumed. Clone 9 cells with an initial cell density of 10,000 per well were seeded in a 24 well culture cluster, grown in clone 9 media and incubated at $37^{\circ} \mathrm{C}$ with $5 \% \mathrm{CO}_{2}$ inside the incubator for day 1 , day 3 and day 7 .

Varying concentrations of synthetic vitamin b12 and vitamin b6 and combination of both vitamins

Synthetic Vitamin B12 and Vitamin B6 stock solutions were created in Clone 9 media. The frozen ampules of synthetic vitamin B6 and synthetic Vitamin B12 were thawed at room temperature and the ampule was opened in the biosafety cabinet. $5 \mathrm{ug} / \mathrm{mL}, 10 \mathrm{ug} /$ $\mathrm{mL}$ and $20 \mathrm{ug} / \mathrm{mL}$ of Vitamin B6 and Vitamin B12 were created from standard stock by serial dilution method and $\mathrm{pH}$ of each solution was measured. Prior to cell seeding into cell culture, the three 24 well cell culture clusters were washed two times using $500 \mathrm{uL}$ of PBS in each well and vacuumed. Clone 9 cells with an initial cell density of 10,000 per well were seeded in 24 well culture cluster coated with $10 \mu \mathrm{g} / \mathrm{mL}$ collagen and grown in clone 9 media. All three plates for day 1 , day 3 and day 7 were prepared by the same method and placed inside the incubator set at $37{ }^{\circ} \mathrm{C}$ with $5 \% \mathrm{CO}_{2}$.

HFF-1 and clone 9 cell analysis

HFF-1 and Clone 9 cells were analyzed by fluorescent staining with calcein to measure the rate of initial adhesion on day 1 and the 
The Effect of Over the Counter and Synthetic Vitamin B6 (Pyridoxine) and Vitamin B12 (Cyanocobalamin) on the Behavior of Liver and Non-Liver Cells

rate of cell proliferation on days 3 and 7. On day 1 after one hour of incubation, two washes were given to the plate by the addition of $0.5 \mathrm{~mL}$ of PBS per well and subsequently removed. A calcein solution consisting of a ratio of $10 \mu \mathrm{L}$ of calcein-AM (Life Technologies, Carlsbad, CA, USA) and $5 \mathrm{~mL}$ of PBS was prepared and used to perform fluorescent staining to obtain a live cell count. $200 \mu \mathrm{L}$ of calcein solution was added into each well and incubated for 15 minutes in a dark incubation drawer. Cell proliferation was measured by using a Filtermax F5 Microplate Reader (Molecular Devices, San Jose, CA, USA). Data were calculated on Microsoft Excel and graphs were created using Microsoft Excel. Fluorescent images were captured under a fluorescent microscope 1 X71 with a Cy3 filter (Olympus ${ }^{\circledR}$, Shinjuku, Tokyo, Japan) at 100x magnification. The exact same procedure was used on days 3 and 7 plates to measure live cell concentrations and analyzed by the same method.

\section{Statistical analysis}

The statistical analysis on the data was presented with the mean \pm standard deviation (SD). A Paired Student $t$-Test was used between the study groups to determine significance of observed differences. A p-value of $<0.05$ is considered statistically significant.

\section{Results}

The effect of collagen and fibronectin matrix on initial cell

adhesion and cell proliferation of clone 9 cells

The initial adhesion rate was first examined, at which cells attached to the surface of the well in the presence of various concentrations of collagen $(5 \mu \mathrm{g} / \mathrm{mL})$, collagen $(10 \mu \mathrm{g} / \mathrm{mL})$, fibronectin $(5 \mu \mathrm{g} / \mathrm{mL})$, or fibronectin $(10 \mu \mathrm{g} / \mathrm{mL})$. Initial adhesion was compared between conditions on day 1 after one hour of incubation. Rate of proliferation for the cells was examined on days 3 and 7 and compared to the control condition with just media. Day 7 test conditions were compared to the day 7 condition with control for statistical significance. Fluorescent staining with calcein was performed to study cell morphology on days 1, 3 and 7.

Clone 9 cells with an initial density of 10,000 per well were seeded onto four separate conditions of collagen $(5 \mu \mathrm{g} / \mathrm{mL})$, collagen $(10 \mu \mathrm{g} / \mathrm{mL})$, fibronectin $(5 \mu \mathrm{g} / \mathrm{mL})$, or fibronectin $(10 \mu \mathrm{g} /$ $\mathrm{mL}$ ). This was an essential step in order to establish which matrix is most suitable for testing the effects of Vitamin B12 and Vitamin
B6. Clone 9 cells that were seeded on the substrate of fibronectin (5 $\mu \mathrm{g} / \mathrm{mL}$ ) displayed the highest rate of initial adhesion. The condition which showed the second greatest amount of initial adhesion for Clone 9 cells was fibronectin $(10 \mu \mathrm{g} / \mathrm{mL})$. The condition of collagen $(5 \mu \mathrm{g} / \mathrm{mL}$ ) had the third best initial adhesion. Finally the collagen $(10 \mu \mathrm{g} / \mathrm{mL})$ condition had the least amount of initial adhesion for Clone 9 cells. Clone 9 cell proliferation was measured on days 3 and 7. Each condition followed the same trend which was on each subsequent day there was more Clone 9 cells present than on the previous, see figure $1 \mathrm{~A}$. Clone 9 cells which were grown on fibronectin $(5 \mu \mathrm{g} / \mathrm{mL})$ had the least amount of proliferation over the 7 day period. This was followed by the fibronectin $(10 \mu \mathrm{g} / \mathrm{mL})$ condition which had the third best proliferation over the same time period. Overall the cells which were seeded onto the collagen conditions proliferated better when compared to fibronectin. Collagen with a concentration of $5 \mu \mathrm{g} / \mathrm{mL}$ had the second best proliferation results out of the four test conditions. Lastly, the condition which had collagen with a concentration of $10 \mu \mathrm{g} / \mathrm{mL}$ provided the best environment for Clone 9 cells to proliferate. The morphology for the Clone 9 cells was consistent across all conditions, see figure 1B. On day 1 Clone 9 cells appear to be round in shape with some displaying a slightly ruffled edge. Next, on day 3 , the cells are more numerous and larger in size when compared to day 1 cells. Day 7 Clone 9 cells were similar in shape to day 3 appearing somewhat cuboidal but they appear to be greater in number when compared to day 3. In addition, the day 7 Clone 9 cells look to be wider in shape when compared to the day 3 cells.

In conclusion, After examining which substrate provided the best environment for cells, it was found that collagen $(10 \mu \mathrm{g} / \mathrm{mL})$ allowed for the highest rate of proliferation over a seven day period while fibronectin $(5 \mu \mathrm{g} / \mathrm{mL})$ conditions had the highest rate of initial adhesion. There was little to no noticeable difference in morphology for the cells between conditions seen.

The effect of over the counter vitamin B6 on HFF-1 cells

The initial adhesion of HFF-1 cells in vitamin B6, at $5 \mathrm{ug} / \mathrm{mL}$, $10 \mathrm{ug} / \mathrm{mL}$ or $20 \mathrm{ug} / \mathrm{mL}$ concentration at Day 1 were compared, see figure $2 \mathrm{~A}$. The greatest initial adhesion was found when grown at $10 \mathrm{ug} / \mathrm{mL}$ where it was $103 \%$ and least when grown at $20 \mathrm{ug} / \mathrm{mL}$ showing $75 \%$ relative to a no-treatment $100 \%$ condition. Regardless of condition, cells treated at a higher concentration of $20 \mathrm{ug} /$ 


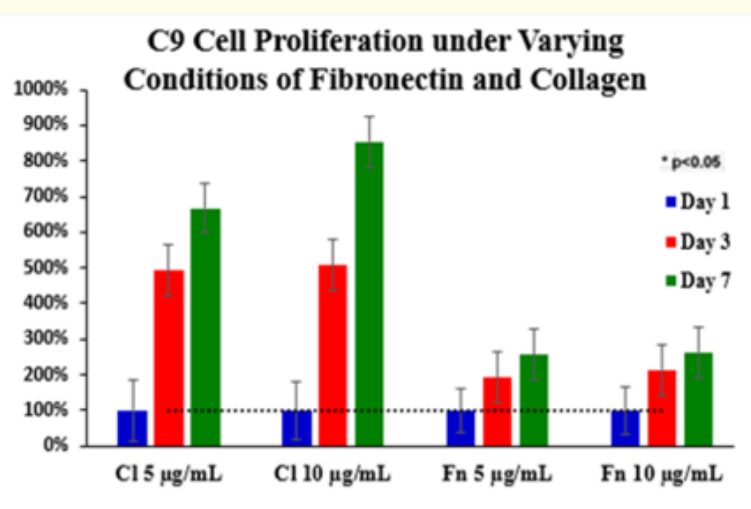

Figure $1 \mathrm{~A}$

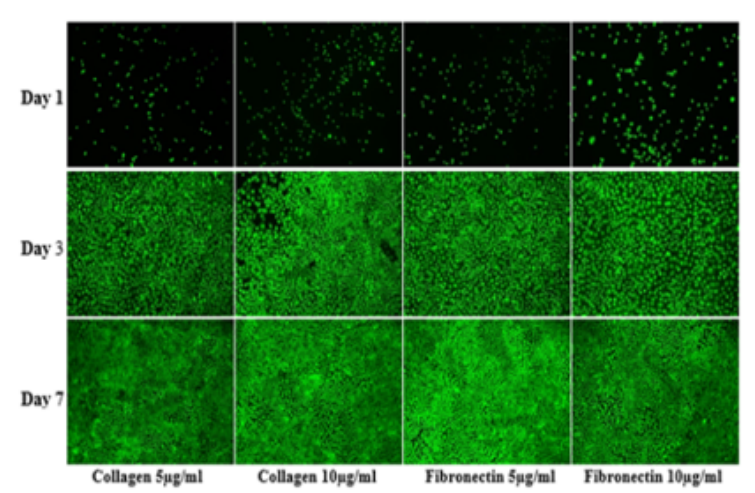

Figure 1B

Figure 1: The Effect of Fibronectin and Collagen on Clone 9 Cells. (A) Clone 9 cells were seeded on substrates of either collagen $(5 \mu \mathrm{g} / \mathrm{mL})$, collagen $(10 \mu \mathrm{g} / \mathrm{mL})$, fibronectin $(5 \mu \mathrm{g} /$ $\mathrm{mL})$, or fibronectin $(10 \mu \mathrm{g} / \mathrm{mL})$ and grown over seven days.

Cellular growth was measured on days 1,3 , and 7 with a calcein treatment and read using a FilterMax F5 Microplate Reader. (B) Images were taken at 100x magnification using Olympus ${ }^{\circledR} 1 \mathrm{X} 71$ fluorescent microscope and Cy3 filter. The statistical analysis on the data was presented with the mean \pm standard deviation (SD). A Paired Student t-Test was used between the study groups to determine significance of observed differences. A *p-value of $<0.05$ is considered statistically significant.

$\mathrm{mL}$ adhered the least as compared to treatment at a lower concentration of $10 \mathrm{ug} / \mathrm{mL}$. Overall, this confirmed that cells were pres-

ent on Day 1. Cell proliferation is expressed as a percentage of the number of cells present on day $1(100 \%)$ therefore day 3 , and day 7 are expressed as a percentage of the number of cells present compared to day 1 . As shown in figure $2 \mathrm{~B}$, the greatest cell proliferation of HFF-1 cells was found when grown with vitamin B6 at $20 \mathrm{ug} /$ $\mathrm{mL}$ and similar results when grown at $5 \mathrm{ug} / \mathrm{mL}$ but did poorly at the $10 \mathrm{ug} / \mathrm{mL}$. When treated with vitamin B6 at 5, 10, $20 \mathrm{ug} / \mathrm{mL}$, HFF-1 cells were still proliferating at Day 3 . However, when treated with vitamin B6 at $10 \mathrm{ug} / \mathrm{mL}$, the cells experienced minimal, if any growth at Day 3, and by Day 7 , even fewer cells were present. On the other hand, HFF-1 cells treated with vitamin B6 at 5 or 20 $\mathrm{ug} / \mathrm{mL}$ exhibit significant proliferation in comparison to the other treatments, with $20 \mathrm{ug} / \mathrm{mL}$ being slightly better. Morphology of HFF- 1 cells can be seen in figure 2C.

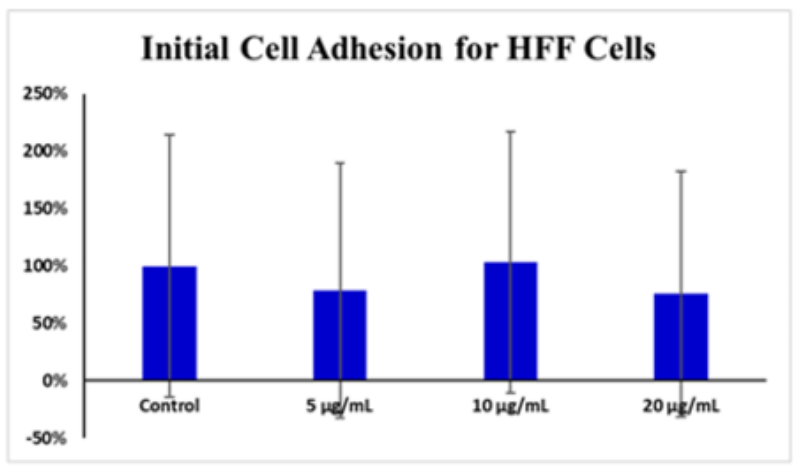

Figure 2A

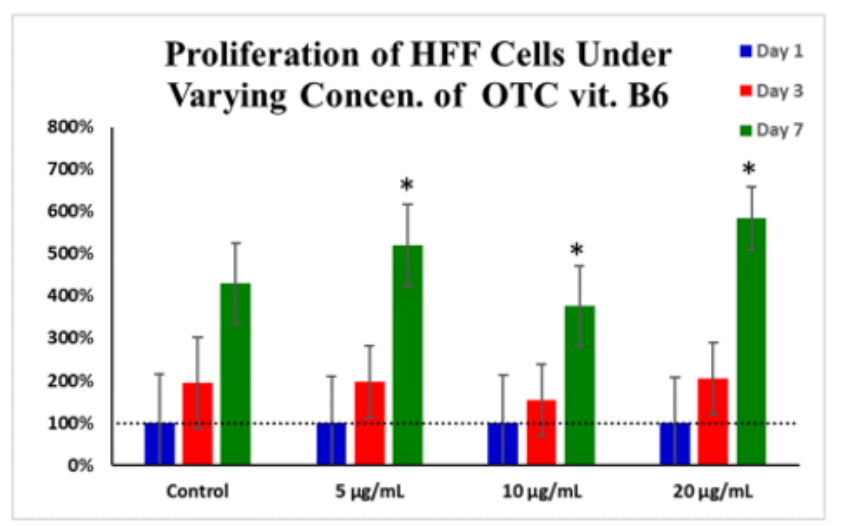

Figure 2B 


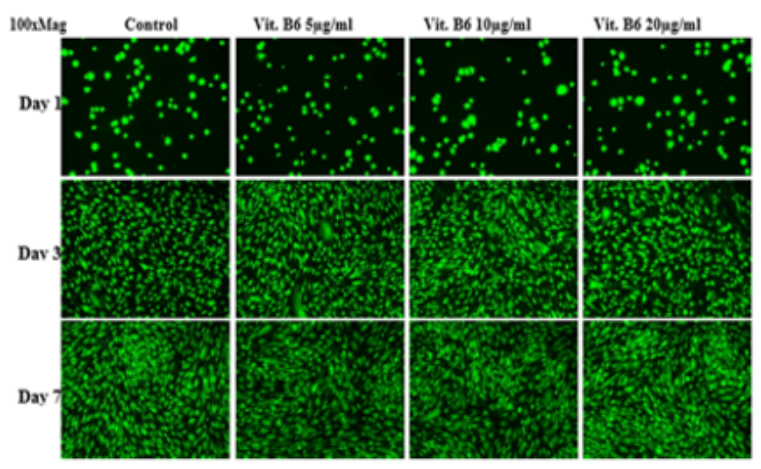

Figure 2C

Figure 2: The effect of Over the Counter Vitamin B6 on HFF-1 Cells. (A) and (B) HFF-1 cells were seeded at an initial density of 10,000 per well in concentrations of either Vitamin B6 (5 $\mathrm{ug} / \mathrm{mL})$, Vitamin B6 (10 ug/mL) or Vitamin B6 (20 ug/mL) for seven days in an incubator at $37^{\circ} \mathrm{C}$ with $5 \% \mathrm{CO}_{2}$. On day 1 , after an hour of incubation, day 3 , and day 7 measurements of proliferation were taken. During those reading, cells were treated with calcein and analyzed using a FilterMax F5 Microplate Reader. (C) Images were taken at 100x magnification using Olympus ${ }^{\circledR} 1 \mathrm{X} 71$ fluorescent microscope and Cy3 filter. The statistical analysis on the data was presented with the mean \pm standard deviation (SD). A Paired Student t-Test was used between the study groups to determine significance of observed differences. A *p-value of $<0.05$ is considered statistically significant.

On Day 1, HFF-1 cells appeared to be round in shape and show a similar size and number between all test conditions. By day 3 , the HFF- 1 cells are spreading on the matrix and become elongated and flattened in shape however, were more numerous when compared to day 1 . The various conditions also appear to be confluent. By day 7 , the cells have spread further across the entire matrix with barely any visible sparse areas being shown. They are more elongated or oblong in shape and are more confluent compared to day 3. Overall, the results showed that there is an increased cell proliferation in the presence of over the counter vitamin B6.
The effect of synthetic vitamin B6 on clone 9 cells

The initial adhesion of Clone 9 cells in vitamin B6, at $5 \mathrm{ug} / \mathrm{mL}$, $10 \mathrm{ug} / \mathrm{mL}$ or $20 \mathrm{ug} / \mathrm{mL}$ concentration at Day 1 were compared, see figure 3A. The greatest initial adhesion was found when grown on $10 \mathrm{ug} / \mathrm{mL}$ where it was $124 \%$ and least adhesive when grown on vitamin $\mathrm{B} 6$ at $20 \mathrm{ug} / \mathrm{mL}, 60 \%$ relative to a no-treatment $100 \%$ condition. The cells that were treated at a higher concentration of 20 $\mathrm{ug} / \mathrm{mL}$ adhered worse than when treated at a lower concentration of $10 \mathrm{ug} / \mathrm{mL}$. Furthermore, when treated with vitamin B6, Clone 9 cells adhere similarly between the $5 \mathrm{ug} / \mathrm{mL}$ vitamin B6 and with no treatment with Vitamin B6. Overall, this confirmed that cells were present at Day 1. Cell proliferation is expressed as a percentage of the number of cells present on day $1(100 \%)$ therefore day 3 , and day 7 are expressed as a percentage of the number of cells present compared to day 1 . As shown in figure $3 \mathrm{~B}$, the greatest cell proliferation of Clone 9 cells was found when grown with vitamin B6 at 20 $\mathrm{ug} / \mathrm{mL}$ and similar results when grown at $5 \mathrm{ug} / \mathrm{mL}$ and control condition, but did poorly at the $10 \mathrm{ug} / \mathrm{mL}$. When treated with vitamin B6 at 5, 10, $20 \mathrm{ug} / \mathrm{mL}$, Clone 9 cells were still proliferating at Day 3. However, when treated with vitamin B6 at $10 \mathrm{ug} / \mathrm{mL}$, the cells experienced minimal, if any growth at Day 3 and, by Day 7 , even fewer cells were present. On the other hand, clone 9 cells treated with vitamin B6 at 5 or $20 \mathrm{ug} / \mathrm{mL}$ exhibit significant proliferation in comparison to the other treatments, with $20 \mathrm{ug} / \mathrm{mL}$ being $50 \%$ better compared to the control. Morphology of Clone 9 cells can be seen in figure 3C. On Day 1, the clone 9 cells of all three conditions are present, numerous, and appear rounded. By Day 3 , cells are spreading on the matrix and appear larger and are more numerous when compared to day 1 . The various conditions also appear to be confluent. By day 7, the cells have spread further across the entire matrix with barely any visible sparse areas being shown. The cells appear larger and the various conditions also appear to be more confluent. Overall, the results showed that there is an increased cell proliferation in the presence of synthetic vitamin B6.

\section{The effect of over the counter vitamin B12 on HFF-1 CellS}

The initial adhesion of HFF-1 cells in vitamin B12 at 0, 5, 10 and $20 \mathrm{ug} / \mathrm{mL}$ concentration at Day 1 were compared, see figure $4 \mathrm{~A}$. The greatest initial adhesion was found when grown on no treatment with Vitamin B12 (control) and the least when grown on vitamin 5 $\mathrm{ug} / \mathrm{mL}$ (71\%), $10 \mathrm{ug} / \mathrm{mL}$ (79\%) and $20 \mathrm{ug} / \mathrm{mL}$ (71\%) all relative to 
a no-treatment (100\%) condition. Overall, this confirmed that cells were present at Day 1. Cell proliferation is expressed as a percentage of the number of cells present on day $1(100 \%)$ therefore day 3 , and day 7 are expressed as a percentage of the number of cells present compared to day 1 . As shown in figure 4B, the greatest cell proliferation of HFF-1 cells was found when grown with vitamin 5 $\mathrm{ug} / \mathrm{mL}$, followed closely by treatment of vitamin B12 at $20 \mathrm{ug} / \mathrm{mL}$, and least when grown with concentration of $10 \mathrm{ug} / \mathrm{mL}$. HFF- 1 cells treated with a vitamin at lower concentrations exhibited significant proliferation. However, when treated with vitamin $10 \mathrm{ug} / \mathrm{mL}$ and $20 \mathrm{ug} / \mathrm{mL}$, the cells experienced minimal, if any, growth difference to one another at Day 3, and by Day 7 , fewer cells were pres-

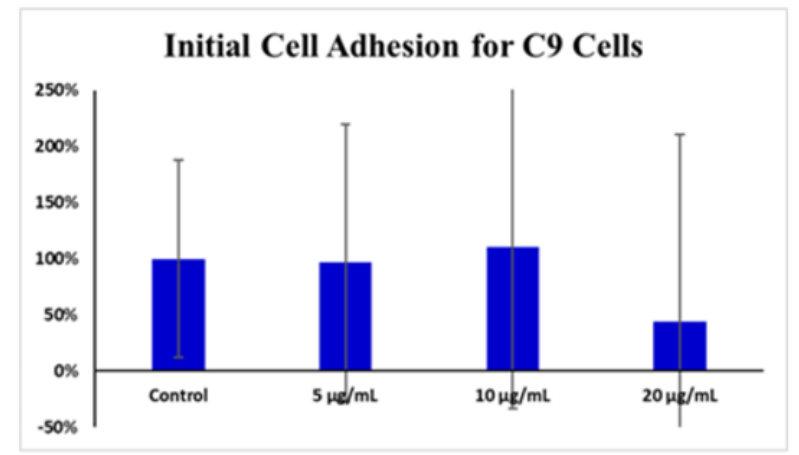

Figure $3 \mathrm{~A}$

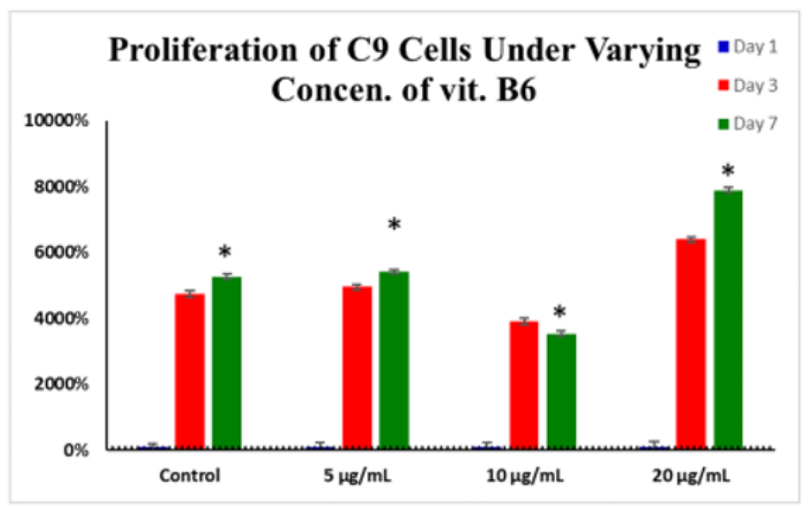

Figure 3B

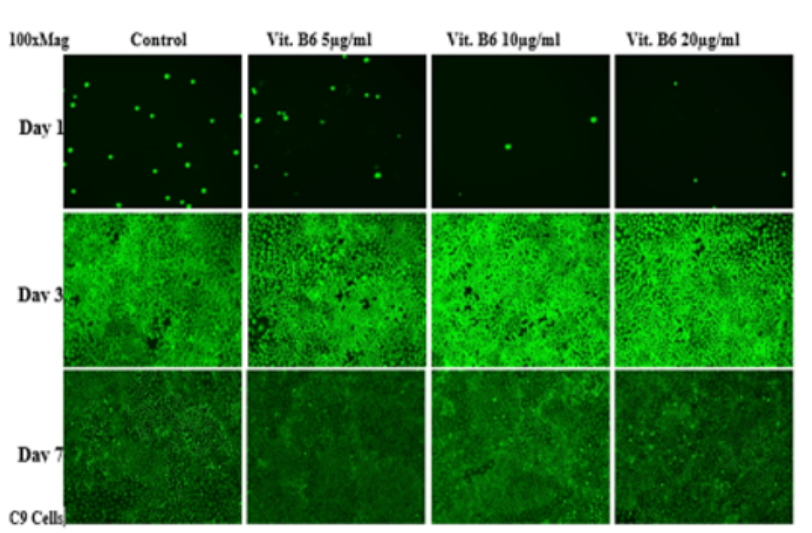

Figure 3C

Figure 3: The Effect of Synthetic vitamin B6 on Clone 9 Cells. (A) and (B) Clone 9 cells were seeded at an initial density of 10,000 per well in concentrations of either Vitamin B6 (5 ug/ $\mathrm{mL}$ ), Vitamin B6 (10 ug/mL) or Vitamin B6 (20 ug/mL) for seven days in an incubator at $37^{\circ} \mathrm{C}$ with $5 \% \mathrm{CO}_{2}$. On day 1 , after an hour of incubation, day 3 , and day 7 measurements of proliferation were taken. During those reading, cells were treated with calcein and analyzed using a FilterMax F5 Microplate Reader. (C) Images were taken at 100x magnification using Olympus ${ }^{\circledR} 1$ X71 fluorescent microscope and Cy3 filter. The statistical analysis on the data was presented with the mean \pm standard deviation (SD). A Paired Student t-Test was used between the study groups to determine significance of observed differences. A *p-value of $<0.05$ is considered statistically significant.

ent on the $10 \mathrm{ug} / \mathrm{mL}$. Morphology of HFF cells can be seen in figure 4C. On Day 1, HFF-1 cells appeared to be round in shape and show a similar size and number between all test conditions. By day 3, the HFF-1 cells are spreading on the matrix and become elongated and flattened in shape with some exhibiting tapered ends however, were more numerous when compared to day 1 . The conditions at vitamin $10 \mathrm{ug} / \mathrm{mL}$ and below appear to be confluent, with vitamin B12 at $20 \mathrm{ug} / \mathrm{mL}$ exhibiting sparse areas. Furthermore, the cells in vitamin B12 at $20 \mathrm{ug} / \mathrm{mL}$ appear larger and more spread out com- 
pared to lower concentrations. By day 7, the cells have spread further across the entire matrix with barely any visible sparse areas being shown. They are more elongated or oblong in shape, larger and are more confluent compared to day 3. Overall, the results showed that there is an increased cell proliferation in the presence of over the counter vitamin B12.

\section{The effect of synthetic vitamin B12 on clone 9 cells}

The initial adhesion of clone 9 cells in synthetic vitamin B12 at $0,5,10$ and $20 \mathrm{ug} / \mathrm{mL}$ concentration at Day 1 were compared, see

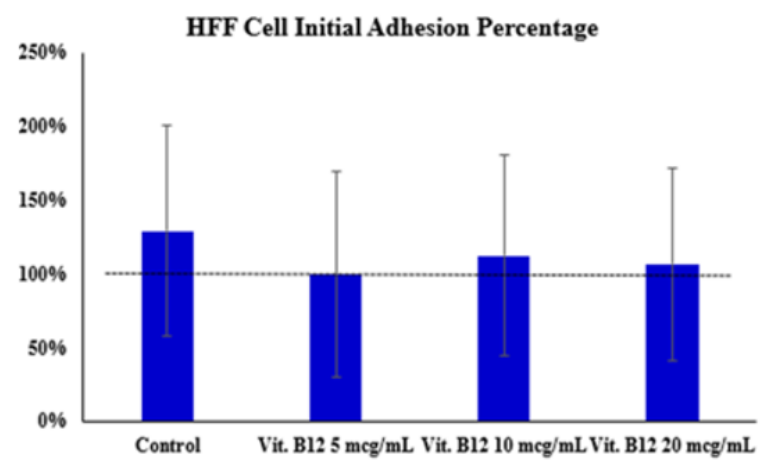

Figure 4A

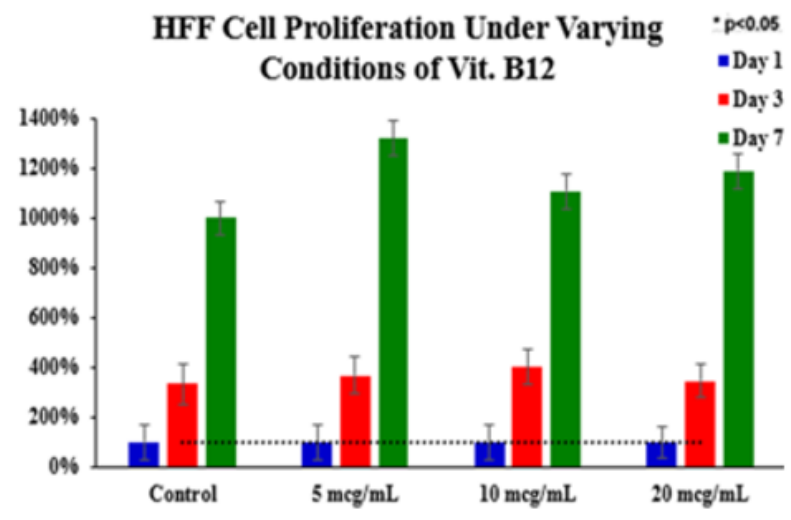

Figure 4B

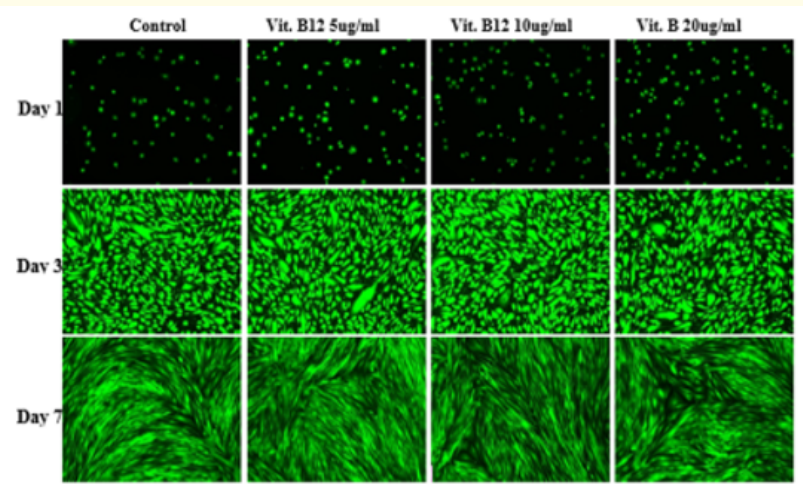

Figure 4C

Figure 4: The Effect of Over the Counter Vitamin B12 on HFF-1 Cells. (A) and (B) HFF-1 cells were seeded at an initial density of 10,000 per well in concentrations of either Vitamin B12 (5 $\mathrm{ug} / \mathrm{mL})$, Vitamin B12 (10 ug/mL) or Vitamin B12 (20 ug/mL) for seven days in an incubator at $37^{\circ} \mathrm{C}$ with $5 \% \mathrm{CO}_{2}$. On day 1 , after an hour of incubation, day 3 , and day 7

measurements of proliferation were taken. During those reading, cells were treated with calcein and analyzed using a FilterMax F5 Microplate Reader. (C) Images were taken at 100x magnification using Olympus ${ }^{\circledR}$ 1X71 fluorescent microscope and Cy3 filter. The statistical analysis on the data was presented with the mean \pm standard deviation (SD). A Paired Student t-Test was used between the study groups to determine significance of observed differences. A *p-value of $<0.05$ is considered statistically significant.

figure 5A. The greatest initial adhesion was found when grown in no treatment of Vitamin B12 (control) and the least when grown on treatment with Vitamin B12 at $5 \mathrm{ug} / \mathrm{mL}$ (47\%), $10 \mathrm{ug} / \mathrm{mL}$ (45\%) and $20 \mathrm{ug} / \mathrm{mL}(60 \%)$ all relative to a no-treatment (100\%) condition. A slight increase is evident with vitamin B12 $20 \mathrm{ug} / \mathrm{mL}$ at the peak and decreasing initial adhesion on lower-end concentrations, the significance between $5 \mathrm{ug} / \mathrm{mL}$ and $10 \mathrm{ug} / \mathrm{mL}$ is around $2 \%$. Overall, this confirmed that cells were present at Day 1. Cell proliferation is expressed as a percentage of the number of cells present on day $1(100 \%)$ therefore day 3 , and day 7 are expressed as a percentage of the number of cells present compared to day 1 . As 
shown in figure $5 \mathrm{~B}$, the greatest cell proliferation of Clone 9 cells was found when grown with vitamin $10 \mathrm{ug} / \mathrm{mL}$, followed closely by treatment of vitamin B12 at $5 \mathrm{ug} / \mathrm{mL}$, and least when grown with concentration $20 \mathrm{ug} / \mathrm{mL}$. Clone 9 cells treated with a vitamin at $10 \mathrm{ug} / \mathrm{mL}$ and lower concentrations exhibited significant proliferation. However, when treated with vitamin $20 \mathrm{ug} / \mathrm{mL}$, the cells experienced minimal, if any growth differences to one another at Day 3, and Day 7 when compared to lower concentrations, fewer cells were present in $20 \mathrm{ug} / \mathrm{mL}$, but still higher compared to the non-treated cells. Morphology of Clone 9 cells can be seen in figure 5C. On Day 1, the clone 9 cells in all conditions are present and appeared rounded. By Day 3 , the cells are spreading on the matrix and appear larger and are more numerous when compared to day 1. The cells' morphology still remains round to some exhibiting a cuboidal shape. All conditions appear to be confluent exhibiting no sparse areas. By day 7, the cells have spread further across the entire matrix with barely any visible sparse areas being shown. The cells in all conditions are more confluent and larger compared to cells in day 3. Overall, the results showed that there is an increased cell proliferation in the presence of synthetic vitamin B12.

The effect of combined over the counter vitamin B12 and vitamin $\mathrm{B} 6$ on clone 9 cells

The initial adhesion of clone 9 cells in combined over the counter vitamin B6 and vitamin B12 at 0, 5, 10 and $20 \mathrm{ug} / \mathrm{mL}$ concen-

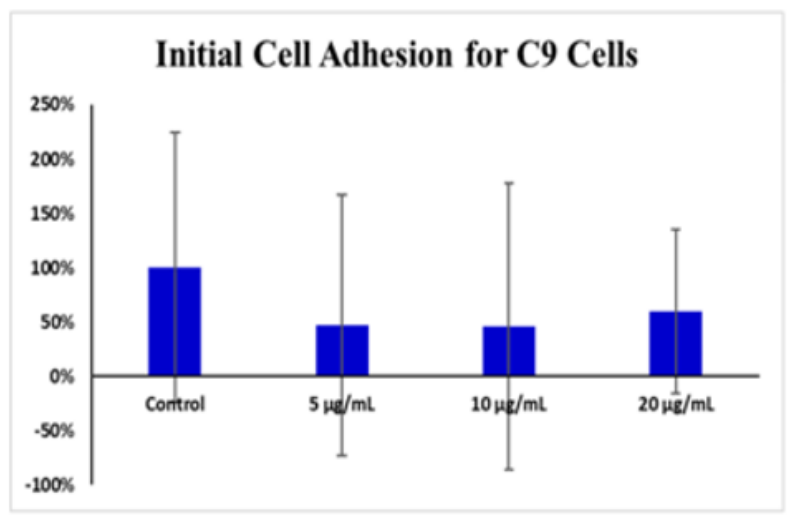

Figure 5A

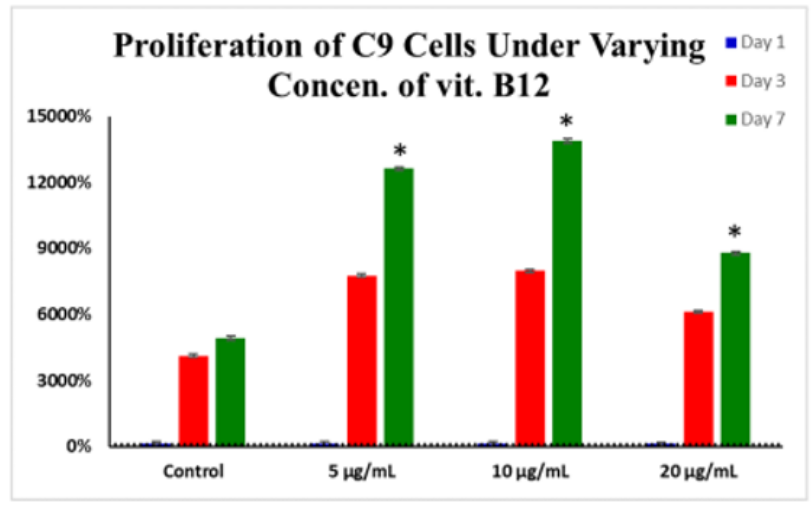

Figure 5B

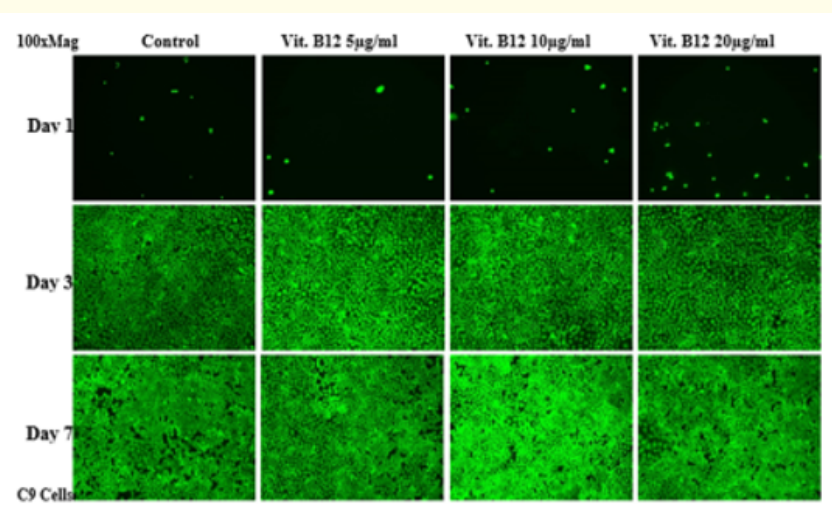

Figure 5C

Figure 5: The Effect of Synthetic Vitamin B12 on Clone 9 Cells. (A) and (B) Clone 9 cells were seeded at an initial density of 10,000 per well in concentrations of either Vitamin B12 (5 $\mathrm{ug} / \mathrm{mL}$ ), Vitamin B12 (10 ug/mL) or Vitamin B12 (20 ug/ $\mathrm{mL}$ ) for seven days in an incubator at $37^{\circ} \mathrm{C}$ with $5 \% \mathrm{CO}_{2}$. On day 1 , after an hour of incubation, day 3 , and day 7 measurements of proliferation were taken. During those reading, cells were treated with calcein and analyzed using a FilterMax F5 Microplate Reader. (C) Images were taken at 100x magnification using Olympus ${ }^{\circledR} 1 \mathrm{X} 71$ fluorescent microscope and Cy3 filter. The statistical analysis on the data was presented with the mean \pm standard deviation (SD). A Paired Student t-Test was used between the study groups to determine significance of observed differences. A *p-value of $<0.05$ is considered statistically significant. 
The Effect of Over the Counter and Synthetic Vitamin B6 (Pyridoxine) and Vitamin B12 (Cyanocobalamin) on the Behavior of Liver and Non-Liver Cells

tration in Day 1 were compared, see figure 6A. The greatest initial adhesion was found when grown in $5 \mathrm{ug} / \mathrm{mL}$ of the combined treatment and the least when grown in $20 \mathrm{ug} / \mathrm{mL}$ and $10 \mathrm{ug} / \mathrm{mL}$ all relative to a no-treatment $(100 \%)$ condition. Overall, this confirmed that cells were present at Day 1 . Cell proliferation is expressed as a percentage of the number of cells present on day 1 $(100 \%)$ therefore day 3 , and day 7 are expressed as a percentage of the number of cells present compared to day 1 . As shown in figure $6 \mathrm{~B}$, the greatest cell proliferation of Clone 9 cells was found when grown in combined vitamin B6 and vitamin B12 at $20 \mathrm{ug} /$ $\mathrm{mL}$, followed closely by the combined treatment of vitamins B6 and $\mathrm{B} 12$ at $10 \mathrm{ug} / \mathrm{mL}$, and least when grown in concentration 5 $\mathrm{ug} / \mathrm{mL}$. When treated with combined vitamins at $20 \mathrm{ug} / \mathrm{mL}$, the cells experienced the greatest proliferation and $10 \mathrm{ug} / \mathrm{mL}$ second, with control condition and $5 \mathrm{ug} / \mathrm{mL}$ showing the least proliferation at Day 3. On Day 7, when compared to lower concentrations, the greatest amount of cells were present in combined treatment of $20 \mathrm{ug} / \mathrm{mL}$ and $5 \mathrm{ug} / \mathrm{mL}$ still showing the least growth. The concentrations of $5 \mathrm{ug} / \mathrm{mL}, 10 \mathrm{ug} / \mathrm{mL}$, and $20 \mathrm{ug} / \mathrm{mL}$ of OTC vitamins B6 and B12 were statistically significant compared to the control. Although none of the measurements for cell initial adhesion were statistically different, the initial adhesion graph shows a clear pattern of inverse proportionality in which $10 \mathrm{ug} / \mathrm{mL}$ and $20 \mathrm{ug} / \mathrm{mL}$ showing the lowest values.

Morphology of Clone 9 cells can be seen in figure 6C. On Day 1 , the clone 9 cells in all conditions are present and appeared rounded. By Day 3, the cells are spreading on the matrix and appear larger and are more numerous when compared to day 1 . The cells' morphology appear round to cuboidal with a distinct dark pigmentation present in most cells. By Day 7, the cells appear larger and more confluent compared to cells in day 3. The dark pigmentation is more pronounced and present in all the individual cells and range from 1 to 3 granules per cell. All conditions in Day 3 and Day 7 appear to be confluent exhibiting no sparse areas. In general, all the treatments of over the counter vitamin B6 and B12 increased the proliferation of the Clone 9 cells, compared to the control. Furthermore, there is a potential evidence of synergistic effect of the combined over the counter formulations on the cells. The occurrence of the dark pigmented granules warrants further investigation.
The effect of combined synthetic vitamin B6 and vitamin B12 on clone 9 cells

The initial adhesion of clone 9 cells in combined synthetic vitamin B6 and vitamin B12 at 0, 5, 10 and $20 \mathrm{ug} / \mathrm{mL}$ concentration in Day 1 were compared, see figure 7A. The greatest initial adhesion was found when grown in the control with no vitamin treatment and the least when grown in $20 \mathrm{ug} / \mathrm{mL} .5 \mathrm{ug} / \mathrm{mL}$ and $10 \mathrm{ug} / \mathrm{mL}$ also showed initial adhesion behavior, however, these were lower

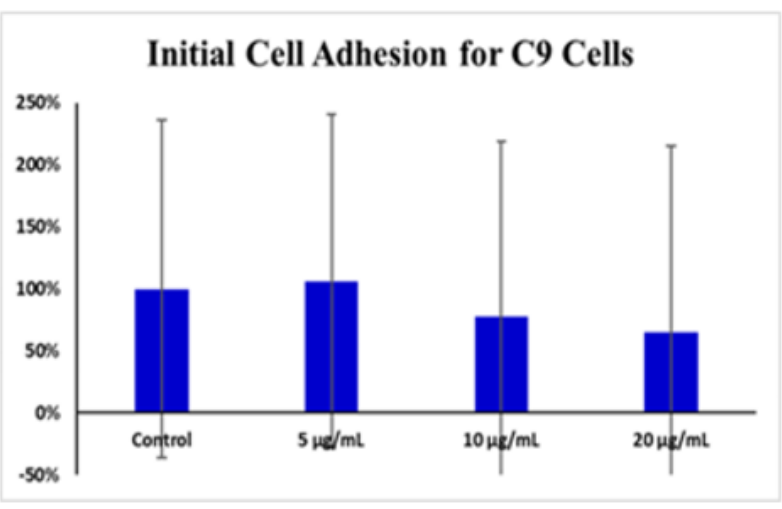

\section{Figure 6A}

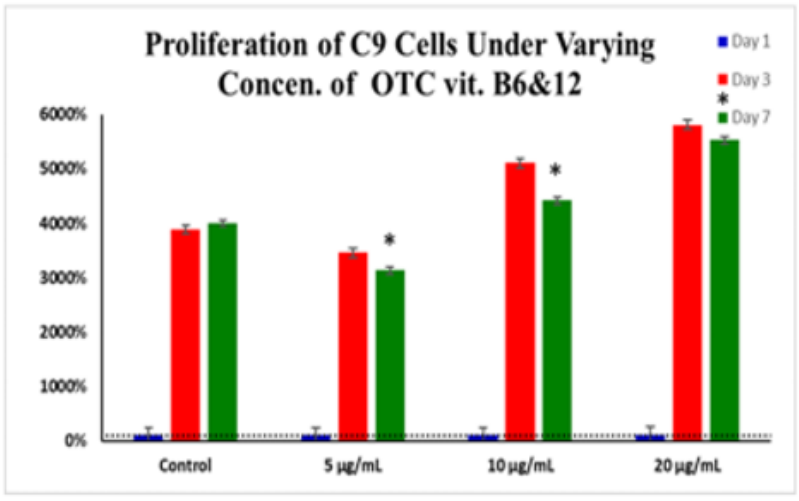

Figure 6B 


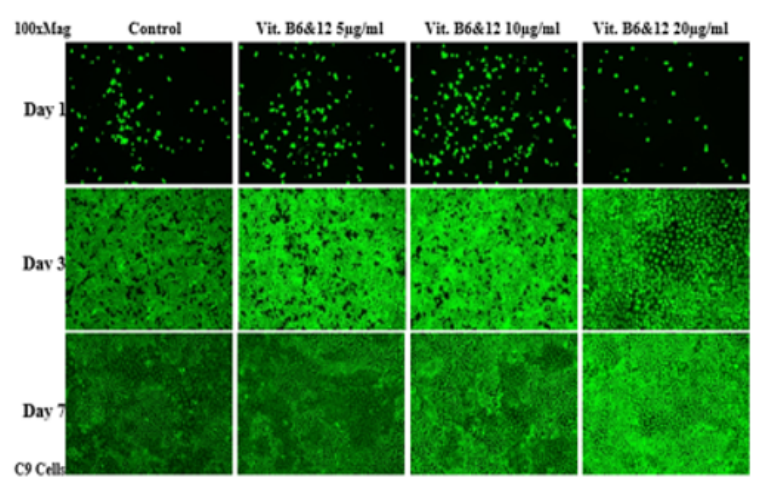

\section{Figure 6C}

Figure 6: The Effect of Combined Over the Counter Vitamin B6 and Vitamin B12 on Clone 9 Cells. (A) and (B) Clone 9 cells were seeded at an initial density of 10,000 per well in concentrations of combined Vitamin 6 and B12 (5 ug/mL), Vitamin B6 and B12 (10 ug/mL) and Vitamin B6 and B12 (20 $\mathrm{ug} / \mathrm{mL}$ ) for seven days in an incubator at $37^{\circ} \mathrm{C}$ with $5 \% \mathrm{CO}_{2}$. On day 1 , after an hour of incubation, day 3 , and day 7 measurements of proliferation were taken. During those reading, cells were treated with calcein and analyzed using a FilterMax F5

Microplate Reader. (C) Images were taken at 100x magnification using Olympus ${ }^{\circledR}$ 1X71 fluorescent microscope and Cy3 filter. The statistical analysis on the data was presented with the mean \pm standard deviation (SD). A Paired

Student t-Test was used between the study groups to determine significance of observed differences. A *p-value of $<0.05$ is considered statistically significant.

than control. Overall, this confirmed that cells were present at Day 1. Cell proliferation is expressed as a percentage of the number of cells present on day $1(100 \%)$ therefore day 3 , and day 7 are expressed as a percentage of the number of cells present compared to day 1 . As shown in figure $7 \mathrm{~B}$, the greatest cell proliferation of Clone 9 cells was found when grown in combined vitamin B6 and vitamin B12 at $20 \mathrm{ug} / \mathrm{mL}$, followed closely by the combined treatment of vitamins B6 and B12 at $10 \mathrm{ug} / \mathrm{mL}$, and least when grown in concentration $5 \mathrm{ug} / \mathrm{mL}$. When treated with combined vitamins at $20 \mathrm{ug} / \mathrm{mL}$, the cells experienced the greatest proliferation and $10 \mathrm{ug} / \mathrm{mL}$ second, with control condition and $5 \mathrm{ug} / \mathrm{mL}$ showing the least proliferation at Day 3. On Day 7, when compared to lower concentrations, the greatest amount of cells were present in combined treatment of $20 \mathrm{ug} / \mathrm{mL}$ and $5 \mathrm{ug} / \mathrm{mL}$ still showing the least growth. There was statistical significance at all three concentrations, $5 \mathrm{ug} / \mathrm{mL}, 10 \mathrm{ug} / \mathrm{mL}$, and $20 \mathrm{ug} / \mathrm{mL}$. The $10 \mathrm{ug} / \mathrm{mL}$ and 20 $\mathrm{ug} / \mathrm{mL}$ are the only two concentrations that show a statistically significant difference compared to Day 7 of the control. Clone 9 cells in $20 \mathrm{ug} / \mathrm{mL}$ synthetic vitamins B6 and B12 reach a Day 7 cell proliferation percent that is two-fold the $20 \mathrm{ug} / \mathrm{mL}$ OTC vitamins B6 and B12. The potential synergistic effect of synthetic combination of vitamin B6 and B12 was evident as the cell proliferation reached rates of almost 10,000\%. Morphology of Clone 9 cells can be seen in figure 7C. On Day 1, the clone 9 cells in all conditions are present and appeared rounded. By Day 3, cells are spreading on the matrix and appear larger and are more numerous when compared to day 1 . The cells' morphology appear round to cuboidal with a distinct dark pigmentation present in most cells. By Day 7, the cells appear larger and more confluent compared to cells in day 3 . The dark pigmentation is more pronounced and present in all the individual cells. These black pigmented granules at or near the center of the cells show further possible evidence of the synergistic effect these B vitamins have on the C 9 cells. All conditions in Day 3 and Day 7 appear to be confluent exhibiting no sparse areas. In general, all the treatments of synthetic vitamin B6 and B12 increased the proliferation of the Clone 9 cells. In all the treatments, it is evident that the combination of the synthetic B vitamins had the highest effect on the Clone 9 cells. Furthermore, there is a potential evidence of synergistic effect of the combined synthetic formulations on the cells. The occurrence of the dark pigmented granules warrants further investigation.

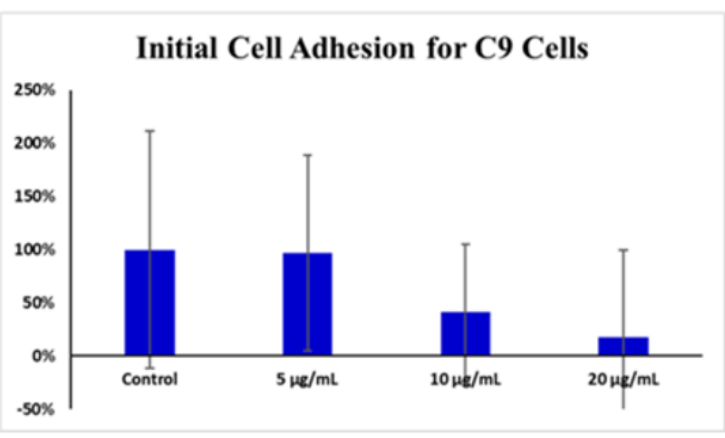

Figure 7A 


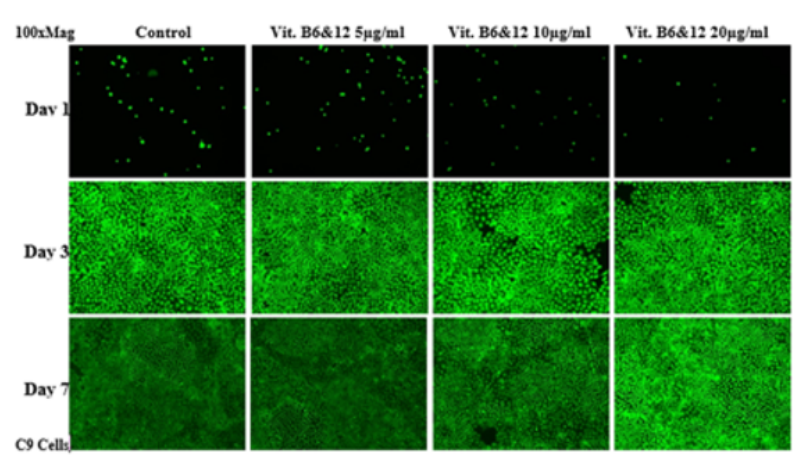

Figure 7C

Figure 7: The Effect of Combined Synthetic Vitamin B6 and Vitamin B12 on Clone 9 Cells (A) and (B) Clone 9 cells were seeded at an initial density of 10,000 per well in concentrations of combined Vitamin 6 and B12 (5 ug/mL), Vitamin B6 and B12 (10 ug/mL) and Vitamin B6 and B12 (20 ug/mL) for seven days in an incubator at $37^{\circ} \mathrm{C}$ with $5 \% \mathrm{CO}_{2}$. On day 1 , after an hour of incubation, day 3 , and day 7 measurements of proliferation were taken. During those reading, cells were treated with calcein and analyzed using a FilterMax F5 Microplate Reader. (C) Images were taken at 100x magnification using Olympus ${ }^{\circledR} 1 \mathrm{X} 71$ fluorescent microscope and Cy3 filter. The statistical analysis on the data was presented with the mean \pm standard deviation (SD). A Paired Student t-Test was used between the study groups to determine significance of observed differences. A *p-value of $<0.05$ is considered statistically significant.

\section{Discussion}

Vitamin B6 or Pyridoxine is one of the most essential molecules in cells of living organisms [13].

It is a critical cofactor for a diverse range of biochemical reactions that regulate basic cellular metabolism [14]. Vitamin B6 consists of a group of six chemically related compounds that all contain a pyridine ring as their core [13]. According to Parra., et al. 2018, these compounds differ from each other in a variable group at the pyridine's $4^{\prime}$ position, which can either be an amino methyl group (pyridoxamine (PM)), a hydroxyl methyl group (pyridoxine $(\mathrm{PN})$ ), or an aldehyde (pyridoxal (PL)). The vitamin has involvement in protein folding [15], amino acid biosynthesis [13,16], degradation of cellular storage compounds [17] and neurotransmitter biosynthesis $[18,19]$.

Vitamin B12 or Cobalamin is essential for DNA synthesis and for cellular energy production [20]. It consists of a number of forms including cyano-, methyl-, deoxyadenosyl- and hydroxy-cobalamin and the cyano form, which is used in supplements, is found in trace amounts in food [21]. The other forms of cobalamin can be converted to the methyl- or 5-deoxyadenosyl forms that are required as cofactors for methionine synthase and L-methyl-malonyl-CoA mutase [20].

In this study, we sought to compare the effects of over the counter and synthetic formulations of vitamin B6 and B12 on HFF-1 cells and Clone 9 normal rat liver cells. Vitamin B6 and B12 are components on vitamin B complex. Several studies have shown that these vitamins have hepatoprotective activities [22]. Initially, in this study, the use of HFF cells was performed to optimize the concentrations needed to be used in the rat liver cells for later investigation. Since the liver is an important organ in the body and performs a fundamental role in the regulation of metabolism, secretion, storage and detoxification [23], hepatic diseases are areas of concern. It is thus necessary to identify substances for the treatment of liver diseases, protection of the liver and regeneration of hepatic cells.

Substrates in cell culture is the surface on which a cell or organism grows or is attached. They are also called extracellular matrices and in the body, they are composed mainly of proteins and provide chemical cues that affect or guide the behavior of cells (Center for Chemical Process Safety, 2019). The two main categories of substrates are naturally-occurring and synthetic. Natural substrates are extracted and purified from tissues to be used in cell culture and the most commonly used are collagen, fibronectin and laminin (ScienCell, 2019). Integrins, which are cell surface receptors bind to domains of these naturally occurring substrates and trigger intracellular signaling pathways that facilitate adhesion complex formation as well as cell proliferation or differentiation. The synthetic substrates are not derived from animal by-products and the most 
The Effect of Over the Counter and Synthetic Vitamin B6 (Pyridoxine) and Vitamin B12 (Cyanocobalamin) on the Behavior of Liver and Non-Liver Cells

commonly used is poly-lysine (ScienCell, 2019). Initially for this study, the substrate needed for the Clone 9 cell line to proliferate was investigated and it showed that collagen offered the most favorable condition.

Clone 9 cells, or rat liver cells, are used within research to understand the functions of liver cells and their reactions to specific molecules [11,12]. Vitamins B6 and B12 are known to enhance cell division (Todorova., et al. 2017) and formation. There is a correlation between the liver and the B vitamins. One study found that more than $25 \%$ of patients with cirrhosis had low levels of thiamine, riboflavin, nicotinic acid, and pyridoxine whereas, $20 \%$ had low levels of vitamin B12, pantothenic acid and biotin [24]. Therefore, Clone 9 rat liver cells were pertinent to investigate the effects of vitamin B6 and B12. In this study, the effects of over the counter and synthetic formulations of Vitamin B6 and Vitamin B12 was investigated separately as well as in combined treatments on liver (Clone 9) and non-liver (HFF-1) cells. In general, it was observed that both the liver and non-liver cells had a favorable rate of proliferation when exposed to these B vitamins.

The results of the several experiments that were performed clearly show that when both liver (Clone 9) and non-liver cell lines (HFF), were exposed to vitamin B6 and B12 in both over the counter and synthetic formulations, cells proliferated at a higher rate compared to the control with no vitamin treatment. Additionally, combined treatments of synthetic vitamin B6 and B12 displayed potential synergistic effects, increasing the cell proliferation almost tri-fold. Since vitamin B6 and B12 are both core vitamins found within the vitamin B-complex components, it is plausible that these vitamins are grouped together in order to increase cell growth and development. This study further demonstrates this hypothesis. The combined synthetic vitamin B6 and B12 cell morphology images also displayed distinctive dark pigmentation at or near the center of each individual cells. This was only evident in the combined treatments of both over the counter and synthetic formulations of vitamin B6 and B12. Some additional studies have found that the B-complex vitamins may actually stimulate stem cell formation, which might explain the cells proliferating at a much higher rate in the combined formulations of vitamin B6 and B12 [25-32].

\section{Conclusion}

In conclusion, the study promotes the use of vitamin B6 and vitamin B12, which are both readily available as dietary supple- ments to aid in the body's overall function. Further investigation is warranted with the observation of dark pigmentation on the center of individual cells with cells treated with combination of vitamin B6 and B12. It is possible that these combinations of treatments enhance the liver cells' proliferative activity and therefore parallel's regeneration of liver cells or it could also possibly demonstrate cell cytotoxicity to these B vitamins. Further recommendations for future study would involve the investigation of liver cells' metabolism with exposure to Vitamin B6 and B12.

\section{Funding Sources}

California State University Channel Islands: Extended University. Department of Biotechnology, Biomedical Engineering Emphasis. One University Drive, Camarillo, California 93012.

\section{Conflict of Interest}

Authors declare that there is no conflict of interest.

\section{Acknowledgements}

The authors would like to thank Melissa McCoy for supporting the group through the experiments and encouraging the research.

\section{Bibliography}

1. Kennedy D. "B Vitamins and the Brain: Mechanisms, Dose and Efficacy-A Review”. Nutrients 8.2 (2016): 68.

2. Gruber K., et al. "Vitamin B12-derivatives-enzyme cofactors and ligands of proteins and nucleic acids". Chemical Society Review 40.8 (2011): 4346-4363.

3. Vasudevan D. "Chapter-34 Water Soluble Vitamins (Thiamine, Riboflavin, Niacin, Pyridoxine, Pantothenic acid, Biotin, Folic acid, Vitamin B12 and Ascorbic acid)". Textbook of Biochemistry (2011): 391-410.

4. Chitambar CR and Antony AC. "Nutritional aspects of haematological diseases". In: Modern nutrition in health and disease; 10th Ed.; Shils ME, Shike M, Ross AC et al, eds. Lippincott Williams and Wilkins (2006): 1436-1461.

5. Romain M., et al. "The role of Vitamin B12 in the critically ill - a review”. Anesthesia Intensive Care 44 (2016): 4.

6. Stabler SP. "Clinical practice. Vitamin B12 deficiency". The New England Journal of Medicine 368 (2013): 149-160.

7. Office of Dietary Supplements - Vitamin B6 (2019). 
The Effect of Over the Counter and Synthetic Vitamin B6 (Pyridoxine) and Vitamin B12 (Cyanocobalamin) on the Behavior of Liver and Non-Liver Cells

8. Skerrett PJ. "Vitamin B12 deficiency can be sneaky, harmful" (2019).

9. Tracy LE., et al. "Extracellular Matrix and Dermal Fibroblast Function in the Healing Wound". Advances in Wound Care 5.3 (2016): 119-136.

10. Eckhart Kyle VN. "The effect of soft drink on proliferation, cell cycle analysis, and integrin expression of human foreskin fibroblast". Journal of Applied Biotechnology and Bioengineering 5.4 (2018): 212-220.

11. ATCC. clone 9 (ATCC® CRL-1439) (2019).

12. Weinstein IB., et al. "Growth and structural properties of epithelial cell cultures established from normal rat liver and chemically induced hepatomas". Cancer Research 35 (1975): 253-263.

13. Parra M., et al. "Vitamin B6 and Its Role in Cell Metabolism and Physiology". Cells 7.7 (2018). pii: E84.

14. Mooney S., et al. "Vitamin B6: A Long Known Compound of Surprising Complexity”. Molecules 14 (2009): 329-351.

15. Cellini B., et al. "The chaperone role of the pyridoxal 5'-phosphate and its implications for rare diseases involving B6-dependent enzymes". Clinical Biochemistry 47 (2014): 158-165.

16. Raschke M., et al. "Enhanced levels of vitamin B (6) increase aerial organ size and positively affect stress tolerance in Arabidopsis". Plant Journal 66 (2011): 414-432.

17. Adeva-Andany MM., et al. "Glycogen metabolism in humans". BBA Clinic 5 (2016): 85-100.

18. Herbison CE., et al. "Low intake of B-vitamins is associated with poor adolescent mental health and behaviour". Preventive Medicine 55 (2012): 634-638.

19. Parletta N., et al. "Nutritional modulation of cognitive function and mental health". Journal of Nutritional Biochemistry 24 (2013): 725-743.

20. O'Leary F and Samman Samir. "Vitamin B12 in Health and Disease". Nutrients 3 (2020): 299-316.

21. Scott JM. "Bioavailability of Vitamin B12". European Journal of Clinical Nutrition 51 (1997): S49-53.

22. Chattopadhyay S., et al. "Hepatoprotective Role of Vitamin B (12) and Folic Acid in Arsenic Intoxicated Rats". Drug and Chemical Toxicology 1 (2012): 81-88.
23. Trefts E., et al. "The Liver". Current Biology 21 (2017): R1147R1151.

24. Mezey E. "Progress In Hepatology Liver Disease and Nutrition". Liver and Nutrition 74.4 (1978).

25. University of Georgia. "Study shows a new role for B-complex vitamins in promoting stem cell proliferation". ScienceDaily (2016).

26. Meyer HE., et al. "Association of High Intakes of Vitamins B6 and B12 From Food and Supplements With Risk of Hip Fracture Among Postmenopausal Women in the Nurses' Health Study". JAMA Network Open 2.5 (2019): e193591.

27. Malouf R and Evans JG. "Folic acid with or without vitamin B12 for the prevention and treatment of healthy elderly and demented people". Cochrane Database of Systematic Reviews (2008).

28. Balk EM., et al. "Vitamin B6, B12, and folic acid supplementation and cognitive function: a systematic review of randomized trials". Archives of Internal Medicine 167.1 (2007): 21-30.

29. Rizzo G., et al. "Vitamin B12 among vegetarians: status, assessment and supplementation". Nutrients 12 (2016): 767.

30. Kubala J. "B-Complex Vitamins: Benefits, Side Effects and Dosage" (2017).

31. Gene expression and carcinogenesis in cultured liver. New York: Academic Press (1975).

32. Todorova TT., et al. "Vitamin B12: Could It Be A Promising Immunotherapy". IntechOpen (2017).

\section{Assets from publication with us}

- Prompt Acknowledgement after receiving the article

- Thorough Double blinded peer review

- Rapid Publication

- Issue of Publication Certificate

- High visibility of your Published work

Website: www.actascientific.com/

Submit Article: www.actascientific.com/submission.php

Email us: editor@actascientific.com

Contact us: +919182824667 